\title{
Technical and economic prefeasibility study of mini-hydro power plants in Venezuela. Case study: El Valle River
}

\author{
${ }^{1 *}$ Victor TREJO, ${ }^{1}$ Gabriela DIAZ, ${ }^{2}$ Luis ROJAS-SOLORZANO, \\ ${ }^{1}$ Simón Bolívar University, Department of Energy Conversion and Transport \\ Sartenejas, Caracas, 1080, Venezuela \\ ${ }^{2}$ Nazarbayev University, Faculty, Department, Institute \\ Astana, 010000, Kazakhstan \\ *E-mail: victormanueltn@gmail.com
}

Keywords: Renewable energies, prefeasibility analysis, hydric resource

\begin{abstract}
The technical and economic feasibility of the installation of a mini-hydroelectric power plant on El Valle River in Venezuela is assessed. Special attention is paid to modeling Venezuela's energetic and economic scenarios. Sensitivity, risk and emission analyses are also carried out. The results of the study show very attractive economic indicators, such as a $280.3 \%$ internal rate of return and a 0.4 years pay-back period. The positive results of the study are indication that clean energies could find very fertile scenarios in countries such as Venezuela, where the advantages of their application may not be evident.
\end{abstract}

\section{Introduction}

Venezuela's income derives almost exclusively from oil exports and it is one of the few countries favored with both, large amounts of fossil fuels and important renewable resources. According to statistics from the International Energy Agency (2013), 68.5\% of the country's internal electricity consumption is produced by hydroelectric power plants and the rest is covered by thermoelectric generation. However, over $87 \%$ of the hydroelectric production comes from a single source, the Simón Bolívar Hydroelectric Central, which ranks as the fourth largest in the world, and no investments in small hydros are scheduled. Investments in thermoelectric power generation are instead currently being carried out. At this moment, Venezuela is also the country with the largest $\mathrm{CO}_{2}$ generation per capita in Latin America (IEA, 2013). This situation, along with typical highly competitive international fuel prices that otherwise would increase internal revenues received from oil exports, extremely needed to fund education and social programs, make Venezuela a very particular scenario for renewable energies. Recent changes in oil prices introduce uncertainty in the described scenario.

The RETScreen $\AA$ V.4 software is a widespread clean energy project analysis tool that facilitates the execution of prefeasibility and feasibility analyses. Several different types of projects have been studied with this tool, a few examples of which are a comparison between landfill gas and waste incineration for power generation in Ghana by Anaglate et al. (2012), the evaluation of prospects of wind farm development in Algeria by Himri et al. (2009) and an environmental, technical and financial feasibility study of solar power plants in Iran by Hajiseyed et al. (2012), the Assessment of the prediction capacity of wind-electric generation models by Romero and Rojas-Solórzano (2014), to mention just a few.

In this work, the technical and economic feasibility of the installation of a mini-hydroelectric power plant on El Valle River in Venezuela is assessed supported on RETScreen $\AA$ software. This paper is organized as follows: In the first two sections, technical and economic feasibility studies and their results are described in detail. Special attention is paid to modeling Venezuela's energetic and economic scenario to assess the viability of the project under these circumstances. Sensitivity and risk analysis complement the prefeasibility study and are presented in section three. In section four, the $\mathrm{CO}_{2}$ emission analysis is described Finally, conclusions are drawn.

\section{Technical analysis}

\section{II.1. Installation site and type of power plant}

The El Valle River in the Los Salias Municipality of the Miranda State, Venezuela, was chosen for this study. The river, along with the streams Cují and El Indio, feed the La Mariposa reservoir. The water from the reservoir flows by gravity into the La Mariposa water purification facility, which, according to Hidrocapital (2013), the company in charge of its operation, has a maximum capacity of $4.3 \mathrm{~m}^{3} / \mathrm{s}$ and provides drinking water to $80 \%$ of Los Altos Mirandinos community and $15 \%$ of Caracas, Venezuela's capital city. In order to minimize investment costs and the effect on the environment, the installation of a run-of-the-river hydroelectric power plant was chosen.

\section{II.2. Evaluation of hydric resource}

The estimate of usable flow was based on hydrological data provided by Venezuela's National Institute of Meteorology and Hydrology (INAMEH). The data comprised monthly average, minimum and maximum flows in the El Valle River during the period 1978-1991 measured at El Valle in la Mariposa hydrological station. With this information, the flow-duration curve in 
fig. 1 was prepared. In accordance with the type of power plant (run-of-the-river) and turbine selection, a flow of $1.25 \mathrm{~m}^{3} / \mathrm{s}$ exceeding $97.7 \%$ was set as design flow for the power plant.

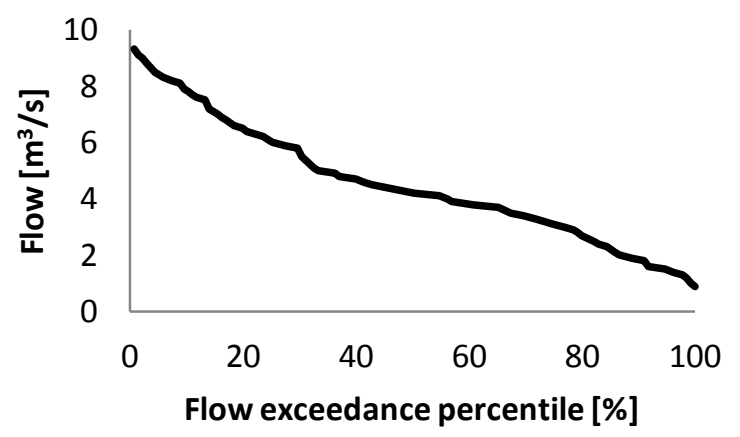

Fig. 1: Flow duration curve of El Valle river

For estimating the available hydraulic head, the computational tool Google Earth was employed. This tool is capable of providing the elevation profile along a trajectory drawn by the user on a satellite view of the terrain. A trajectory along the El Valle River was traced in order to estimate the hydraulic head. The resulting elevation profile is shown in fig. 2 with two arrows indicating possible positions for the flow intake and the turbine. The section limited by these two positions has an horizontal length of $0.55 \mathrm{~km}$ and a hydraulic head of $40 \mathrm{~m}$.

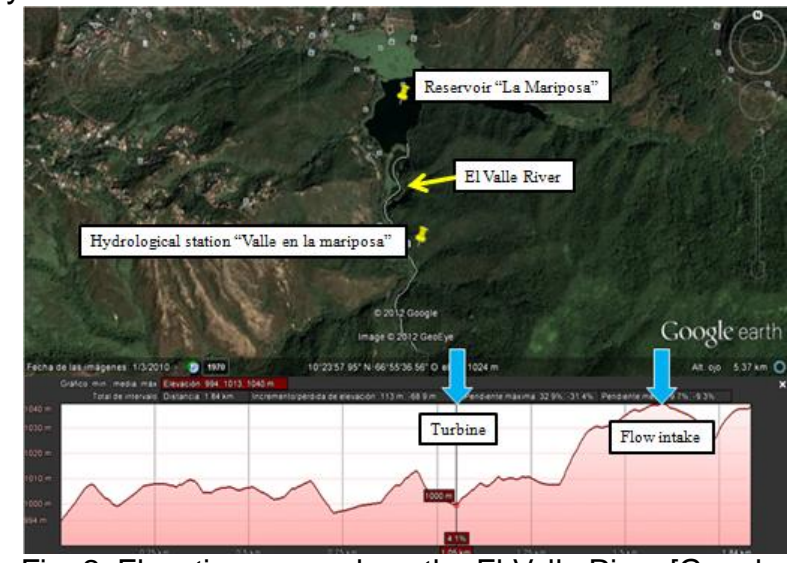

Fig. 2: Elevation curve along the El Valle River [Google Earth, 2012]

\section{II.3. Turbine selection}

Based on the available flow and head, a Francis turbine emerged as the most appropriate unit ("Minicentrales hidroeléctricas - Manual de energías renovables", 2006). A $405 \mathrm{~kW}$ turbine along with its accessories (generator, governor, excitation system, main inlet valve, spare parts and special tools) were chosen from the catalogue of a manufacturer and its characteristics are summarized in table 1.

Table 1: Key characteristics of selected turbine

\begin{tabular}{|c|c|}
\hline \multicolumn{2}{|c|}{ Turbine features } \\
\hline Max head & $42 \mathrm{~m}$ \\
\hline Design head & $40 \mathrm{~m}$ \\
\hline Runner diameter & $0.5 \mathrm{~m}$ \\
\hline Design flow & $1.25 \mathrm{~m}^{3} / \mathrm{s}$ \\
\hline Unit output & $405 \mathrm{~kW}$ \\
\hline Turbine efficiency & $89 \%$ \\
\hline
\end{tabular}

\begin{tabular}{|c|c|}
\hline Generator efficiency & $92.5 \%$ \\
\hline Frequency & $60 \mathrm{~Hz}$ \\
\hline
\end{tabular}

The annual production of energy was estimated taking into consideration the operating conditions of the turbine, its type and flow-duration curve, a typical power curve and the generator-turbine efficiencies. The obtained projected annual energy is $3121 \mathrm{MWh}$, which shows that the El Valle River is adequate for the installation of a mini-hydroelectric power plant.

\section{Economic analysis}

The economic prefeasibility analysis was carried out in the RETScreen® V.4 software. Electricity prices in Venezuela are very low since they are subsidized by the government, which means that investing in electricity generation is not profitable for any private entity unless some sort or arrangement is agreed upon with the authorities. Therefore, the study was carried out from the perspective that the only possible investor is the Venezuelan government, for whom the investment may be beneficial in the sense that it opens up the opportunity for substituting thermoelectric generation and exporting the fuels that would have been otherwise consumed. The modeling of the project is described in detail in this section.

\section{III.1. Value of the produced $\mathrm{kWh}$}

Electricity prices in Venezuela has been subsidized under regulation since the year 2002 as indicated by the official gazette from April 3th (2002) and do not reflect inflation rates. For this reason, using the commercialization price of electricity as the value of the produced $\mathrm{kWh}$ underestimates greatly the economic impact of any generation project in the country. Since Venezuela is an oil producer and exporter, each kWh produced via renewable energies translates into a $\mathrm{kWh}$ that is not produced in thermoelectric power plants and can thus be exported at considerably higher international rates.

The investment in renewable sources of energy competes directly with the ongoing expansion of Venezuela's thermoelectric installed capacity. More specifically, hydroelectric power currently competes with power generation with gasoil (diesel); according to Venezuela's Centro Nacional de Despacho (2010) generation with fueloil and natural gas decreased $0.57 \%$ and $6.77 \%$, respectively in the year 2010 with respect to 2009, while generation with gasoil increased $25.4 \%$. Therefore, the value of the saved $\mathrm{kWh}$ was set to $\$ 242 / \mathrm{MWh}$ according to gasoil prices reported by the IEA (2012) for the date of the modeling and after considering the efficiency of a typical diesel power plant according to the U.S. Energy Information Administration (2013).

\section{III.2. Financial parameters}

A project life of 50 years was considered since hydroelectric power plants can operate for over 50 years without major overhauls. A yearly average escalation rate for gasoil was calculated with available data corresponding to the period 2007-2014 and an average U.S. inflation rate was calculated with data 
corresponding to the period 1980-2010 (Index Mundi, 2014). The obtained value of the former is $1.1 \%$ and for the latter $2.6 \%$. For the discount rate, a value of $10 \%$ was chosen, which corresponds to a typical return value of Venezuelan U.S. $\$$ bonds

\section{III.3. Costs}

The costs of the selected turbine and related equipment are detailed in table 2 and in total add US $\$ 104000$, which representsthe highest portion of the initial costs.

Table 2: Costs of turbine and related equipment

\begin{tabular}{|c|c|}
\hline Equipment & Cost [US \$] \\
\hline Turbine & 38000 \\
\hline Generator & 25000 \\
\hline Governor & 17000 \\
\hline Excitation system & 12000 \\
\hline Main inlet valve & 6000 \\
\hline $\begin{array}{c}\text { Spare parts and } \\
\text { special tools }\end{array}$ & 6000 \\
\hline
\end{tabular}

The costs of the feasibility study, development and engineering were estimated as $10 \%$ of the equipments and civil work costs, and equal to $8.4 \%$ of the initial costs. As reported by the Instituto para la Diversificación y Ahorro de Energía (2006), civil works for a hydroelectric power plant typically represent $40 \%$ of the initial costs. This is a conservative value for a run-of-the-river installation and it is meant to account for any contingencies. Transportation fees for the equipments were calculated as $\$ 10000$, near $10 \%$ of the equipments costs.

3 months were estimated as the time necessary for the construction and start up of the power plant. It was estimated that during this period, 2 engineers, 3 technicians and 3 manual workers would be required. Additionally, the turbine provider demands a supervisor and the future operator of the power plant would require training during this period. The costs associated to the described personnel are detailed in table 3 . The salary of the supervisor is fixed by the provider, while the rest of the salaries were calculated based on Venezuela's labor market.

Table 3: Salaries of staff during construction and start up

\begin{tabular}{cccc}
\hline Quantity & Position & $\$ /$ month & Total \\
\hline 1 & Supervisor & 2400 & 2400 \\
2 & Engineers & 1860 & 3720 \\
3 & Technicians & 1290 & 3870 \\
3 & Manual workers & 1000 & 3000 \\
1 & Operator & 1290 & 1290 \\
\hline \multicolumn{5}{c}{ Complete staff } \\
(3 months) & $\$ 40260$ \\
\hline
\end{tabular}

\section{III.4. Results of the prefeasibililty study}

The economic indicators resulting from the prefeasibility analysis carried out are summarized in table 4.

Table 4: Economic indicators of the project's profitability

\begin{tabular}{cc}
\hline Indicator & Value \\
\hline Internal rate of return & $280.30 \%$ \\
Pay-back period & 0.4 years \\
Net present value & US $\$ 7992008$ \\
Equivalent anual savings & US\$804 050 \\
Benefit-cost ratio & 30.77 \\
\hline
\end{tabular}

As the resulting economic indicators show, the herein described project would be highly profitable, the investment of which would be recovered rather quickly (1.1 years) and that would produce benefits during its complete lifetime. The study shows a very high internal rate of return $(280.30 \%)$, which is quite superior to the discount rate $(10 \%)$. Figure 3 shows the growth of the Net Present Value in the cumulative cash flow during the project's lifetime. The benefit-cost ratio indicates that for each dollar invested, $\$ 30.77$ will be gained including all expenditures, which equates to $\$ 804050$ as annual savings.

\section{III.5. Risk analysis}

The economic gains of the project are achieved through gasoil savings and sales. Fuel prices are difficult to predict since they depend heavily on international politics. For these reasons, it is especially important to assess the possible impact of a decrease in the price of gasoil on the profitability of the project. Sensitivity and risk analyses were carried out.

In the sensitivity analysis, the effects of possible variations of initial costs, maintenance costs and the price of gasoil (modeled as the electricity export rate) on the internal rate of return, the net present value and the pay-back period were considered. Results are summarized in table 5 and show that the most influential factor is the price of gasoil followed by the initial costs. The price of gasoil has a strong influence on all three economic indicators, while the initial costs impact the internal rate of return and the pay-back period mostly. The operation and maintenance costs do not show an important relative impact.

Table 5: Results of sensitivity analysis

\begin{tabular}{|c|c|c|c|}
\hline \multirow{2}{*}{ Parameter } & \multicolumn{3}{|c|}{ Relative impact (-) } \\
\cline { 2 - 4 } & $\begin{array}{c}\text { Internal rate } \\
\text { of return }\end{array}$ & $\begin{array}{c}\text { Pay-back } \\
\text { period }\end{array}$ & $\begin{array}{c}\text { Net present } \\
\text { value }\end{array}$ \\
\hline Gasoil price & 0.8 & -0.8 & 1 \\
\hline Initial costs & -0.55 & 0.6 & $>-0.1$ \\
\hline $\begin{array}{c}\text { Operation and } \\
\text { Maintenance } \\
\text { costs }\end{array}$ & $>-0.1$ & $<0.1$ & $>-0.1$ \\
\hline
\end{tabular}

Following the results of the sensitivity analysis, the influence of the price of gasoil and the initial costs on the profitability of the project were quantified with the risk analysis. A wide sensitivity range of $50 \%$ was considered for both factors, i.e., scenarios that combined variations of each factor ranging from $50 \%$ 
to $150 \%$ of the original values were considered. The results of the risk analysis are shown in tables 5 and 6 for the internal rate of return and pay-back period, respectively.

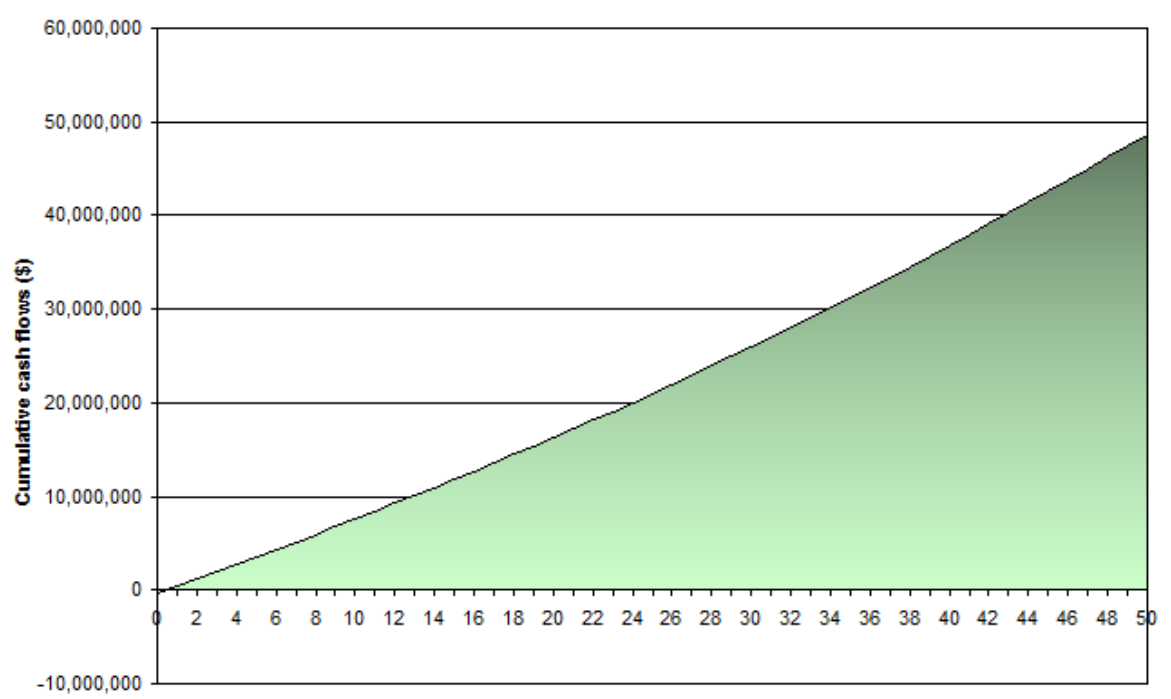

Fig. 3: Cummulative cash flow

Table 6: risk analysis for the internal rate of return

\begin{tabular}{|c|c|c|c|c|c|}
\hline $\begin{array}{r}\text { Initial costs } \\
\text { variation [\%] } \\
\text { Price of }\end{array}$ Gasoil variation [\%] & -50 & -25 & 0 & 25 & 50 \\
\hline-50 & $274 \%$ & $183 \%$ & $138 \%$ & $110 \%$ & $92 \%$ \\
\hline-25 & $417 \%$ & $278 \%$ & $209 \%$ & $167 \%$ & $140 \%$ \\
\hline 0 & $559 \%$ & $373 \%$ & $280 \%$ & $224 \%$ & $187 \%$ \\
\hline 25 & $702 \%$ & $468 \%$ & $352 \%$ & $282 \%$ & $235 \%$ \\
\hline 50 & $845 \%$ & $564 \%$ & $423 \%$ & $339 \%$ & $282 \%$ \\
\hline & & & & \\
\hline
\end{tabular}

An increase of $50 \%$ in the initial costs and a decrease of $50 \%$ in the price of gasoil result in the worst case scenario: an internal rate of return of $92 \%$ and a pay-back period of 1.1 years. These are less attractive, but still very profitable indicators, which shows that, even though the project is very sensitive to variations in initial costs and the price of gasoil, it can still be profitable when facing very unfavorable scenarios such as recent changes in oil price, as long as the gap between gasoil production costs and its sale price remains wide enough.

Table 7: risk analysis for pay-back period

\begin{tabular}{|c|c|c|c|c|c|}
\hline $\begin{array}{r}\text { Initial costs } \\
\text { Price of } \begin{array}{c}\text { variation [\%] } \\
\text { Gasoil variation [\%] }\end{array}\end{array}$ & -50 & -25 & 0 & 25 & 50 \\
\hline-50 & 0.4 & 0.5 & 0.7 & 0.9 & 1.1 \\
\hline-25 & 0.2 & 0.4 & 0.5 & 0.6 & 0.7 \\
\hline 0 & 0.2 & 0.3 & 0.4 & 0.4 & 0.5 \\
\hline 25 & 0.1 & 0.2 & 0.3 & 0.4 & 0.4 \\
\hline 50 & 0.1 & 0.2 & 0.2 & 0.3 & 0.4 \\
\hline
\end{tabular}

\section{Emission analysis}

Due to the high demand that the Venezuelan electrical network has been experiencing since the energy crisis of 2009 , new thermoelectric plants have been installed along the Venezuelan territory in the recent years.

With the installation of the mini-hydropower plant in the El Valle River, it is possible to contribute to the relief of the already existing network.

Since the electric grid is overloaded, the proposed mini hydropower plant would displace the thermoelectric power plants that are to be installed, likewise contributing to reduce the fuel consumption required for the operation of these new thermoelectric plants and thus, the greenhouse gases emissions. To determine the amount of emissions that would be reduced with the proposed project, an analysis of emissions was performed.

The resulting savings in greenhouse gases emission resulting from this study is 3079t of equivalent $\mathrm{CO}_{2}$ per year. Some equivalent measures to better visualize this benefit may be considered: 3079t $\mathrm{CO} 2$ are equivalent to removing 564 automobiles from circulation, to avoid consuming 7160 barrels of gasoline or 1322961 l of gasoline per year.

\section{Conclusions}

A technical and economic prefeasibility study of the installation of a mini-hydroelectric power plant on the El Valle River in Venezuela was carried out. The technical prefeasibility study showed that the El Valle River reunites the necessary characteristics for the installation of a run-of-the-river hydroelectric power plant.

The economic prefeasibility study was carried out from the perspective that, taking Venezuela's very particular energetic and economic characteristics in consideration, the national government is the only possible investor. The results of the study show very attractive economic indicators, such as a $280.3 \%$ internal rate of return, a 0.4 years pay-back period and a 30.77 benefit-cost ratio.

Sensitivity and risk analyses demonstrated that, even when facing highly unfavorable variations in gasoil prices and initial costs, the project can still be profitable. 
The emission analysis' results indicate possible annual reductions of greenhouse gases emissions equivalent to 3079 t CO2.

The profitability of the project, as well as its environmental advantages, is enhanced by the fuel savings and possible export. Both, economic and environmental attractiveness of the installation of the mini-hydroelectric power plant are strongly reinforced by Venezuela's current energetic and economic characteristics. In this sense, the positive results of the study are indication that clean energies could find very fertile scenarios in countries such as Venezuela, where the advantages of their application may not be evident.

\section{References}

Anaglate, S. A., Rahmaputro, S., Ruiz, C. \& Rojas-Solórzano, L. R., 2012. Comparison between landfill gas and waste incineration for power generation in Accra, Ghana. International Journal of Environmental Science and Engineering Research, Volume 3, pp. 1-7.

Banco Central de Venezuela, 2012. Banco Central de Venezuela - Indicadores. [Online]

Available at: http://www.bcv.org.ve/c2/indicadores.asp

[Accessed 10 noviembre 2012].

Centro Nacional de Despacho, 2010. scribd. [Online]

Available

at:

http://es.scribd.com/doc/58926153/Comentarios-Centro-Naci onal-de-Despacho-Informe-2010

[Accessed 05 November 2013].

Google Earth. 2012: El Valle River Satellite View $10^{\circ} 23^{\prime} 57.95 \mathrm{~N} 66^{\circ} 55^{\prime} 36.56 \mathrm{O}$, Elevation 1024M. [Online]. Accessed November 2013, Available: http://www.google.com/earth/index.html

González, D., 2012. Revista económica de Venezuela. [Online]

Available

at:

http://revistaeconomicadevenezuela.blogspot.com/2011/04/s

alario-nominal-en-venezuela-1999-2011.html

[Accessed 10 November 2012].

Hajiseyed Mirzahosseini, A. \& Taheri, T., 2012. Environmental, technical and financial feasibility study of solar power plants by RETScreen, according to the targeting of energy subsidies in Iran. Renewable and Sutainable
Energy Reviews, 16(5), pp. 2806-2811.

Hidrocapital, 2013. Hidrocapital. [Online]

Available

at:

http://www.hidrocapital.com.ve/internet/index.php?option=co m_content\&view=article\&id=162:plantas-de-tratamiento-ii\&c atid=7:nuestras-plantas-de-tratamiento\&ltemid $=45$

[Accessed 2013 November 2013].

Himri, Y., Boundghene Stambouli, A. \& Draoui, B., 2009. Prospects of wind farm development in Algeria. The International Journal on the Science and Technology of Desalting and Water Purification, 239(1-3), pp. 130-138.

Instituto para la Diversificación y Ahorro de Energía, 2006. Minicentrales hidroeléctricas - Manual de energías renovables. In: Madrid: s.n., p. 53.

International Energy Agency, 2012. International Energy Agency. [Online]

Available at: http://www.eia.gov/petroleum/gasdiesel/

[Accessed 02 July 2012].

International Energy Agency, 2013. [Online]

Available

at:

http://www.iea.org/statistics/statisticssearch/report/?\&country $=$ VENEZUELA\&year $=2011$ \&product $=$ ElectricityandHeat

[Accessed 5 November 2013].

Ministerio del Poder Popular para la Energía Eléctrica, 2013. Ministerio del Poder Popular para la Energía Eléctrica. [Online]

Available at: http://mppee.gob.ve/inicio/guriinfo

[Accessed 5 November 2013].

Ministerios de la Producción y del Comercio y de la Energía y Minas, 2002. Universidad del Zulia. [Online]

Available

at:

http://www.arq.luz.edu.ve/personales/rcuberos/cursos/postgr ado/servicios/documentos/normas/gacetatarifaselectricas.pd f

[Accessed 5 Novermber 2013].

RETScreen® International, 2004. Clean Energy Project Analysis: RETScreen $\AA$ Engineering \& Cases Textbook. Canada: s.n.

Romero, M. N. \& Rojas-Solórzano, L. R., 2014. Assessment of the Prediction Capacity of a Wind-Electric Generation Model. International Journal of Renewable Energy \& Biofuels, Volumen 2014.

U.S. Energy Information Administration, 2013. EIA. [En línea] Available

http://www.eia.gov/tools/faqs/faq.cfm?id=107\&t=3

[Accessed: 12 2013]. 